ANDRIOLO JL; JANISCH DI; DAL PICIO M; SCHMITT OJ; LERNER MA. 2014. Nitrogen accumulation and monitoring by strawberry stock plants for runner tips production. Horticultura Brasileira 32: 273-279. DOI - http://dx.doi.org/10.1590/S0102-05362014000300006

\title{
Nitrogen accumulation and monitoring by strawberry stock plants for runner tips production
}

\author{
Jerônimo L Andriolo; Djeimi I Janisch; Miriane Dal Picio; Odair J Schmitt; Maíne A Lerner \\ UFSM-CCR, Depto. Fitotecnia, Av. Roraima 1000, 97105-900 Santa Maria-RS; jeronimoandriolo@gmail.com; djeimi_agro@yahoo. \\ com.br; miriandedalpicio@yahoo.com.br; odairschmitt@yahoo.com.br; mainelerner@yahoo.com.br
}

\begin{abstract}
The composition and concentration of the nutrient solution can affect growth of strawberry stock plants and runner tips production. The aim of this research was to determine runner tips production and nitrogen $(\mathrm{N})$ accumulation by strawberry stock plants grown under five $\mathrm{N}$ concentrations in the nutrient solution and its relationships with chlorophyll meter readings. From September 2010 to March 2011, strawberry stock plants of cultivar Oso Grande and Camino Real were grown on sand polyethylene bags. Nitrogen was supplied by nutrient solutions at concentrations of $5.12(\mathrm{C} 1), 7.6(\mathrm{C} 2), 10.12$ (C3), 12.62 (C4) and 15.12 (C5) mmol L-1. Runner tips bearing at least one expanded leaf were collected weekly and counted. The chlorophyll index (ICF) was measured fortnightly using a digital chlorophyll meter on the last second full expanded leaf of stock plant. A polynomial relationship was adjusted between the chlorophyll index and the $\mathrm{N}$ concentration in leaflets, which can be used for monitoring the $\mathrm{N}$ status of this crop. Leaflets and petioles are the organs of the strawberry stock plants with the higher $\mathrm{N}$ accumulation and runner tips production is not affected by $\mathrm{N}$ concentrations of the nutrient solution in the range of 5.12 to $15.12 \mathrm{mmol} \mathrm{L}^{-1}$.
\end{abstract}

Keywords: Fragaria x ananassa, vegetative propagation, nutrition.

\section{RESUMO}

Acúmulo e monitoramento do nitrogênio em plantas matrizes de morangueiro para produção de pontas de estolão

A composição e concentração da solução nutritiva podem afetar o crescimento de plantas matrizes de morangueiro e a produção de pontas de estolões. O objetivo deste trabalho foi determinar a produção de pontas de estolões e o acúmulo de nitrogênio $(\mathrm{N})$ por plantas matrizes de morangueiro cultivadas em cinco concentrações de $\mathrm{N}$ na solução nutritiva e suas relações com o teor de clorofila. De setembro de 2010 a março de 2011, plantas matrizes das cultivares Oso Grande e Camino Real foram cultivadas em sacos de polietileno contendo areia. $\mathrm{O} N$ foi fornecido pela solução nutritiva nas concentrações de 5,12 (C1), 7,6 (C2), 10,12 (C3), 12,62 (C4) e 15,12 (C5) mmol L-1. As pontas de estolão que apresentavam pelo menos uma folha expandida foram coletadas semanalmente e contadas. O índice de clorofila (ICF) foi medido, quinzenalmente utilizando clorofilômetro portátil digital, na penúltima folha completamente expandida da planta matriz. Uma relação polinomial foi ajustada entre o ICF e a concentração de N nos folíolos, que pode ser usada para monitorar o teor de $\mathrm{N}$ da cultura. Concluiu-se que os folíolos e os pecíolos são os órgãos das plantas matrizes de morangueiro que mais acumulam $\mathrm{N}$ e que a produção de pontas de estolões não é afetada por concentrações de $\mathrm{N}$ na solução nutritiva entre 5,12 e $15,12 \mathrm{mmol} \mathrm{L}^{-1}$.

Palavras-chave: Fragaria $x$ ananassa, propagação vegetativa, nutrição.

(Recebido para publicação em 2 de outubro de 2013; aceito em 10 de junho de 2014)

(Received on October 2, 2013; accepted on June 10, 2014)

S trawberry is a perennial species, but in Brazil it is grown as annual. Planting is done every year to reduce risks of pests and diseases and maximize yield and quality. Nowadays, high quality transplants delivered to growers at the best time for planting is the major handicap of this crop in Southern Brazil. Bare root transplants are the traditional strawberry propagation method but there is nowadays a trend to replace it by plug transplants in trays. Main advantages of strawberry plug transplants are higher survival after planting, better crop stand and higher yield (Hochmuth et al., 2006). For using the plug plant method, a high source of runner tips at the right time is necessary. For this goal, hydroponical facilities have been used (Bish et al., 2001). Cultivar, environmental conditions and crop practices like the composition and concentration of the nutrient solution can affect growth of stock plants and runner tips production.

Data about the effect of nitrogen (N) on emission of runner tips are controversy. They were enhanced by decreasing the $\mathrm{N}$ concentration of the nutrient solution from 120 to
$30 \mathrm{mg} \mathrm{L}^{-1}$ (Bish et al., 2001). In bare root transplants, the $\mathrm{N}$ concentration increased in roots and crown, but starch and other nonstructural carbohydrates decreased, resulting in further higher early fruit yield (Méndez et al., 2009; Kirschbaum et al., 2010). In wild strawberry species, the number of stolons was increased by $\mathrm{N}$ concentrations in the range from 0 to $5 \mathrm{mmol} \mathrm{L}^{-1}$ (Tworkoski et al., 2001). In a NFT (Nutrient Film Technique) hydroponic system, Darnell \& Stutte (2001) reported that N uptake rates and tissue $\mathrm{N}$ concentration in plants grown at $\mathrm{NO}_{3}^{-}-\mathrm{N}$ concentrations of 
3.75, 7.5 and $15.0 \mathrm{mmol} \mathrm{L}^{-1}$ increased, but no effect was observed on nitrate reductase (NR) activity in leaves and roots, neither in vegetative nor fruit dry weight. However, the NR activity is affected by the nitrate-ammonium ratio (Tabatabaei et al., 2008). It was higher at the ratio of $15 \%$ ammonium, while the $\mathrm{NO}_{3}$ concentration in leaves was reduced in 5\% (Taghavi et al., 2004).

In horticultural crops, the indirect measure of chlorophyll by using hand held meters has been proposed as a tool for managing $\mathrm{N}$ fertilization (Gianquinto et al., 2010). In strawberry plants, significant linear positive relationships have been adjusted between SPAD readings and total $\mathrm{N}$ content in several cultivars (Güler et al., 2006). However, great variability of $\mathrm{N}$ concentration in leaves was recorded among cultivars, showing the need to calibrate the chlorophyll meter for each cultivar or group of cultivars.

The aim of this research was to determine $\mathrm{N}$ accumulation and runner tips production by strawberry stock plants grown under five $\mathrm{N}$ concentrations in the nutrient solution and its relationships with chlorophyll meter readings.

\section{MATERIAL AND METHODS}

The experiment was conducted from September 2010 to March 2011, inside a polyethylene greenhouse in Santa Maria state, Rio Grande do Sul, Brazil (2942'S; 5342'W, 95 m altitude). Average air temperatures and global solar radiation during the experimental period was, respectively: $17.46^{\circ} \mathrm{C}$ and $1164.80 \mathrm{~kJ} \mathrm{~m}^{-2}$ in September, $17.7^{\circ} \mathrm{C}$ and $1509.87 \mathrm{~kJ} \mathrm{~m}^{-2}$ in October; $20.34^{\circ} \mathrm{C}$ and $1584.27 \mathrm{~kJ} \mathrm{~m}^{-2}$ in November; $23.33^{\circ} \mathrm{C}$ and $1704.34 \mathrm{~kJ} \mathrm{~m}^{-2}$ in December; $24.5^{\circ} \mathrm{C}$ and $1713.75 \mathrm{~kJ} \mathrm{~m}^{-2}$ in January; $24.04^{\circ} \mathrm{C}$ and $1424.05 \mathrm{~kJ} \mathrm{~m}^{-2}$ in February. A closed soilless system was used. The substrate was sand in $0.21 \mathrm{~m}$ diameter and $1.2 \mathrm{~m}$ length white polyethylene bags. Sand physical characteristics were 0.01-0.03 $\mathrm{m}$ gauge, $1.6 \mathrm{~kg} \mathrm{dm}^{-3}$ bulk density and $0.243 \mathrm{~L} \mathrm{dm}^{-3}$ maximum water retention capacity. Bags were placed over benches at $0.80 \mathrm{~m}$ height above the soil. The nutrient solution was supplied to each plant six times a day for $15 \mathrm{~min}$ by drip fertigation at a rate of $1.4 \mathrm{~L} \mathrm{~h}^{-1}$ from a polyethylene reservoir for optimal water and nutrient availability to plants.

The nutrient solution reported by Hennion \& Veschambre (1997) for the strawberry crop was used as control, adjusted to nutrient concentrations of, in mmol L'- $8.26 \mathrm{NO}_{3}^{-}, 1.86 \mathrm{NH}_{4}^{+}, 4$ $\mathrm{H}_{2} \mathrm{PO}_{4}^{-}, 6 \mathrm{~K}^{+}, 2 \mathrm{Ca}^{+2}, 1 \mathrm{Mg}^{+2}$ and $1 \mathrm{SO}_{4}^{-2}$. Micronutrients quantities were, in $\mathrm{mg}$ $\mathrm{L}^{-1}, 0.03 \mathrm{Mo}$; 0.42 B; 0.06 Cu; 0.50 Mn; $0.22 \mathrm{Zn}$ and $1.0 \mathrm{Fe}$.

Treatments were five $\mathrm{N}$ concentrations in the nutrient solution: 5.12 (C1), 7.62 (C2), 10.12 (C3 control), 12.62 (C4) and 15.12 (C5) mmol L-1. Such concentrations were in the range of those reported in the literature for soilless strawberry crops (Gimenez et al., 2008). The electrical conductivities (EC) were $1.09 ; 1.3 ; 1.6 ; 1.76$ and $2.0 \mathrm{dS}$ $\mathrm{m}^{-1}$, respectively. The $\mathrm{pH}$ was adjusted in the range between 5.5 and 6.5 , by $\mathrm{H}_{3} \mathrm{PO}_{4}$ or $\mathrm{KOH} 1 \mathrm{~N}$ additions whenever necessary. The cultivars Oso Grande and Camino Real were used, in a $5 \mathrm{x}$ 2 factorial randomized experimental design and twenty replications of one plant. Separated units of the hydroponic growing system were used for each nutrient concentration. Fertilizers were potassium nitrate $\left(38.7 \% \mathrm{~K}^{+}\right.$and $13.8 \%$ $\left.\mathrm{N}-\mathrm{NO}_{3}{ }^{-}\right)$, ammonium nitrate $(30.0 \%$ $\mathrm{N})$, calcinit ${ }^{\circledR}\left(14.4 \% \mathrm{~N}^{-\mathrm{NO}_{3}}{ }_{3}^{-} ; 1.1 \%\right.$ $\mathrm{N}-\mathrm{NH}_{4}^{+}$and $\left.19 \% \mathrm{Ca}^{+2}\right)$, potassium monophosphate $\left(28.7 \% \mathrm{~K}^{+}\right.$and $22.8 \%$ $\left.\mathrm{H}_{2} \mathrm{PO}_{4}^{-}\right)$, potassium sulphate $(44.9 \%$ $\mathrm{K}^{+}$and $18.4 \% \mathrm{SO}_{4}^{-2}$ ) and magnesium sulphate $\left(9.9 \% \mathrm{Mg}^{+2}\right.$ and $\left.18.4 \% \mathrm{SO}_{4}^{-2}\right)$. Nitrogen concentrations were differed by modifying ammonium nitrate and potassium sulphate quantities in the nutrient solution. Ionic concentrations of $\mathrm{H}_{2} \mathrm{PO}_{4}^{-}, \mathrm{Ca}^{+2}, \mathrm{Mg}^{+2}$ and $\mathrm{K}^{+}$were as the control in all treatments and concentration of $\mathrm{SO}_{4}^{-2}$ was $2 \mathrm{mmol} \mathrm{L}^{-1}$ in $\mathrm{C} 1$.

Micropropagated stock plants of both cultivars were acclimatized and planted in bags on September 22, 2010. The bags were arranged in four lines at a plant density of 12 plants $\mathrm{m}^{-2}$, with $4.5 \mathrm{dm}^{3}$ of substrate for each plant. Runner emission on $50 \%$ plants of each treatment started on October 17, 2010 and proceeds until March
3, 2011. During this experimental period, all runner tips bearing at least one expanded leaf (patent requested) were weekly collected and the crown diameter measured using a caliper. Senescent leaves on stock plants were periodically removed.

Fortnightly, from October 16 to the end of the experiment, relative leaf chlorophyll content, expressed by Chlorophyll Index (ICF), was determined using a digital chlorophyll meter (clorofiLOG ${ }^{\circledR}$ CFL 1030, Falker). The ICF is a dimensionless measure of total $(a+b)$ chlorophyll obtained from absorbance of chlorophylls in three wave lengths. For calibration, 30 leaves were sampled on stock plants, the ICF determined using the chlorophyll meter and the actual chlorophyll $(\mathrm{a}+\mathrm{b})$ concentration in $\mathrm{mg} \mathrm{g}^{-1}$ of fresh weight in the same leaves was determined in the laboratory (Hiscox \& Israelstam, 1979). A relationship between ICF and chlorophyll was adjusted: $\mathrm{Chl}(\mathrm{a}+\mathrm{b})=$ $0.0467 \mathrm{ICF}-0.0529, \mathrm{R}^{2}=0.86$, for Oso Grande and Chl $(\mathrm{a}+\mathrm{b})=0.0607 \mathrm{ICF}$ $1.0047 \mathrm{R}^{2}=0.95$ for Camino Real. The ICF readings were made on all three leaflets of the last second full expanded leaf of the main crown on twenty plants per treatment, between 8:00 and 10:00 am and averaged to obtain the ICF of the plant.

The $\mathrm{N}$ concentration in runner tips was determined in the laboratory in samples collected on January 26, 2011. The experiment was ended on March 3, 2011. Six stock plants of each treatment were collected and separated into leaflet, petioles, crown, roots and runner tips. Dry mass was determined after drying at $65^{\circ} \mathrm{C}$ until constant mass was reached. Total $\mathrm{N}$ and $\mathrm{N}_{-} \mathrm{NO}_{3}-$ in tissues were determined by micro-Kjeldahl (Tedesco et al., 1995).

Results were submitted to analysis of variance and the significance of differences among means was determined by Tukey test $(\mathrm{p}<0.05)$ or polynomial regression using de software STATISTICA $^{\circledR}$. Data of all replications were used for adjusting regresions.

\section{RESULTS AND DISCUSSION}

Number of runner tips did not 


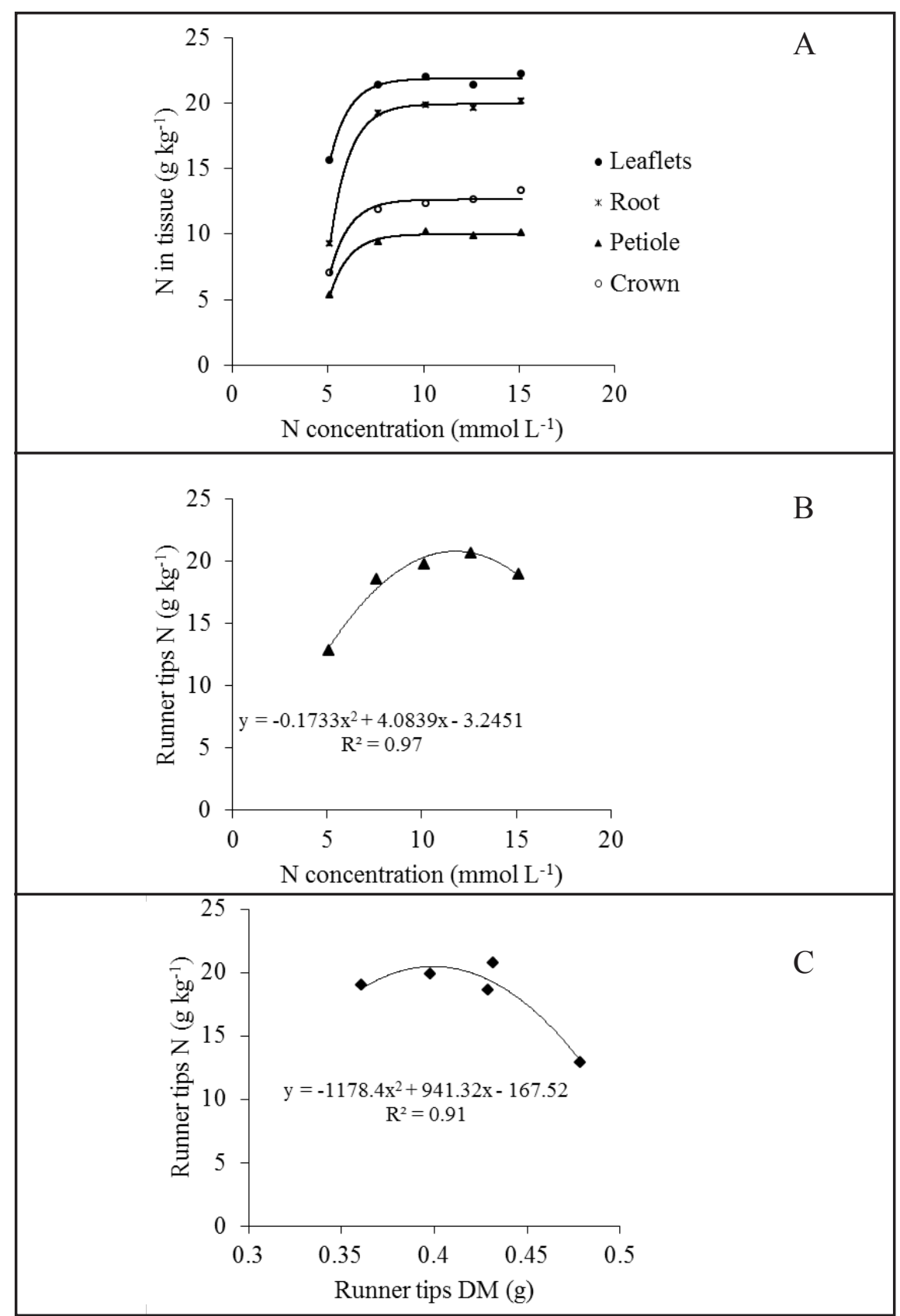

Figure 1. Nitrogen $(\mathrm{N})$ concentration in stock plant tissues $(\mathrm{A})$ and in runner tips $(\mathrm{B})$ and relationship between dry matter and nitrogen accumulation in runner tips $(\mathrm{C})$ of strawberry plants grown under nitrogen concentrations from 5.12 to $15.12 \mathrm{mmol} \mathrm{L}^{-1}$ in the nutrient solution [concentração de nitrogênio $(\mathrm{N})$ na planta mãe $(\mathrm{A})$ e nas pontas de estolão $(\mathrm{B}) \mathrm{e}$ relação entre a acumulação de massa seca e de nitrogênio nas pontas de estolão de plantas de morangueiro cultivadas em concentrações de nitrogênio de 5,12 a $15,12 \mathrm{mmol} \mathrm{L}^{-1}$ na solução nutritiva]. Santa Maria, UFSM, 2011.

differ between cultivars and among $\mathrm{N}$ concentrations in the nutrient solution $(p>0.05)$. Nevertheless, the $\mathrm{N}$ concentration in tissues differed by effect of its concentration in the nutrient solution and also among plant organs (Figure 1). The lowest tissue concentration was recorded at the lowest nutrient solution concentration $(\mathrm{C} 1)$ in $\left.\mathrm{g} \mathrm{kg}^{-1}\right)$ and higher in roots $\left(17.80 \mathrm{~g} \mathrm{~kg}^{-1}\right)$ and leaflets $\left(20.60 \mathrm{~g} \mathrm{~kg}^{-1}\right)(\mathrm{p} \leq 0.05)$. Of the total $\mathrm{N}$ uptake by plants, $62.4 \%$ was accumulated in leaflets, $16.4 \%$ in roots, $14.5 \%$ in petioles and $6.75 \%$ in the crown. The lowest proportion in the crown was due to its low dry matter, which represented on average $10 \%$ of the whole plant. In runner tips, tissue $\mathrm{N}$ concentration showed a polynomial pattern by effect of its concentration in the nutrient solution (Figure 1B). The maximum estimated concentration was $20.8 \mathrm{~g} \mathrm{~kg}^{-1}$ at $11.8 \mathrm{mmol} \mathrm{L}^{-1} \mathrm{~N}$ in the nutrient solution.

Nitrate concentration in tissues differed among organs and cultivars (Figures 2A, B). The lowest average concentration was $0.69 \mathrm{mg} \mathrm{g}^{-1}$ in leaflets of Camino Real and the highest 3.06 $\mathrm{mg} \mathrm{g}^{-1}$ in petioles of Oso Grande. In roots, Camino Real showed 25\% higher nitrate concentration than Oso Grande. Nitrate concentration was $32 \%$ higher in the crown, $22 \%$ in petioles and $26 \%$ in leaflets of Oso Grande plants $(\mathrm{p} \leq 0.05)$ (Figure 2C).

Relationships between chlorophyll index measurements and $\mathrm{N}$ concentration determined at the laboratory were adjusted (Figure 3). Nitrogen concentration in leaflets of the whole plant can be estimated by the polynomial equation for both cultivars in the range between 14.8 and 22.05 $\mathrm{g} \mathrm{kg}^{-1} \mathrm{~N}$ (Figure 3A). The total plant $\mathrm{N}$ concentration can also be estimated from the $\mathrm{N}$ concentration in leaflets by a linear equation for both cultivars (Figure 3B).

Data of chlorophyll index on leaflets of both cultivars at the end of the experiment showed polynomial patterns for the $\mathrm{N}$ concentration in the nutrient solution (Figure 3A). Chlorophyll index in the plant decreased at concentrations in the nutrient solution upper than $11.6 \mathrm{mmol} \mathrm{L}^{-1}$ (data not shown). At such concentrations the electrical conductivity was in the range between $1.76 \mathrm{dS} \mathrm{m}^{-1}$ (C4) and $2.0 \mathrm{dS} \mathrm{m}^{-1}$ (C5), and salinity effects like water stress could have taken place. It has been reported in the literature that salt stress negatively affected the growth, chlorophyll content and mineral uptake of strawberry plants (Karlidag et al., 


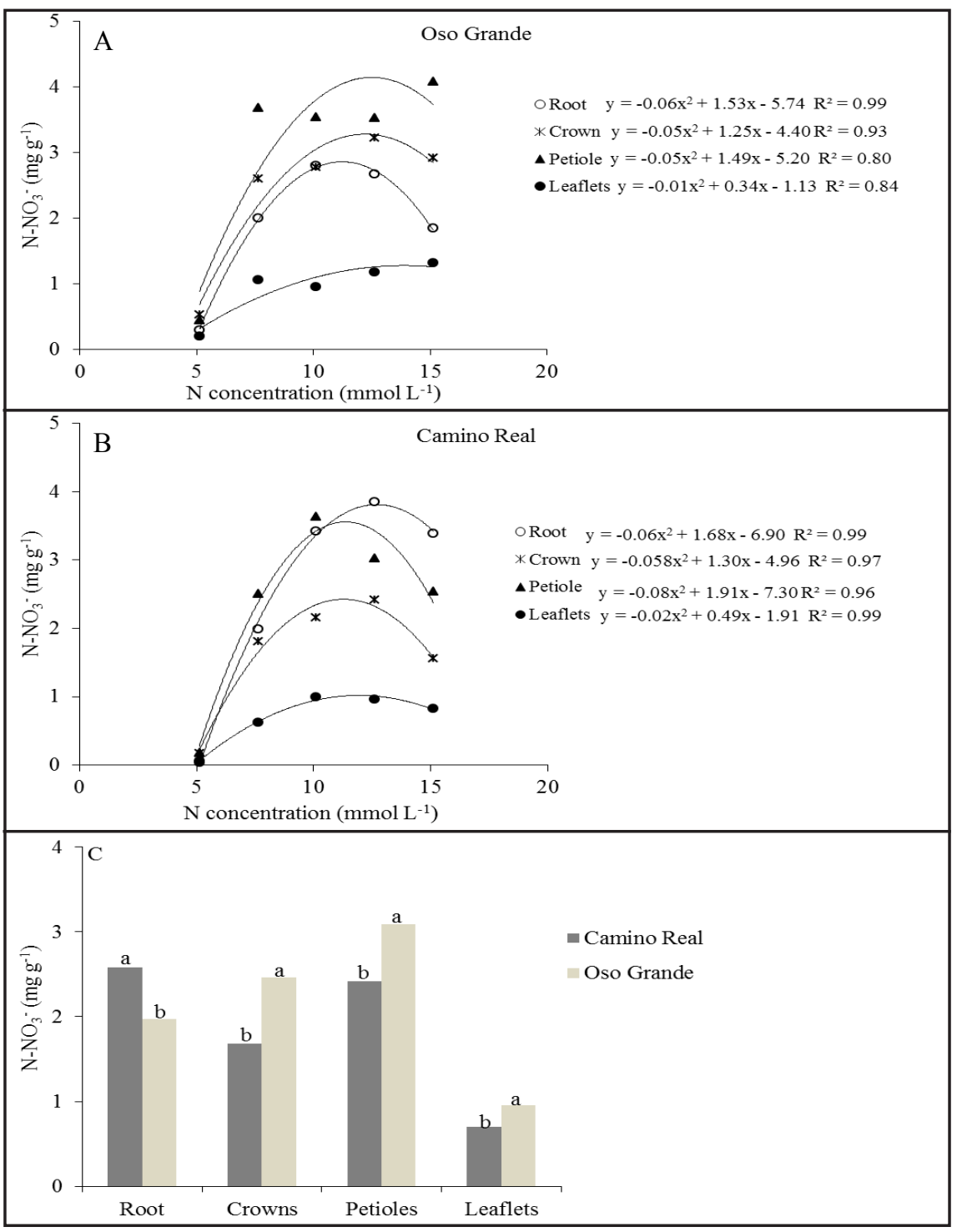

Figure 2. Nitrate $\left(\mathrm{N}-\mathrm{NO}_{3}\right)$ concentration in organs of Oso Grande (A) and Camino Real (B) strawberry stock plants grown under nitrogen $(\mathrm{N})$ concentrations from 5.12 to $15.12 \mathrm{mmol}$ $\mathrm{L}^{-1}$ in the nutrient solution and average of nitrate concentration in organs of both cultivars (C). Means followed by the same letters do not differ by the F test, $5 \%$ [concentração de nitrato $\left(\mathrm{N}_{-} \mathrm{NO}_{3}^{-}\right)$nos órgãos de plantas matrizes de morangueiro das cultivares Oso Grande (A) e Camino Real (B) cultivadas com concentrações de nitrogênio (N) entre 5,12 e 15,12 mmol L-1 na solução nutritiva e concentração média de nitrato nos órgãos das duas cultivares (C)]. Santa Maria, UFSM, 2011.

2009). But, when data of measurements made at fortnight intervals during all the growing period were pooled together, a linear pattern was adjusted and the chlorophyll index was highest at the highest $\mathrm{N}$ concentration in the nutrient solution (Figure 3C). During the growing period of plants, chlorophyll index decreased $10 \%$ in Oso Grande leaves and $16 \%$ in Camino Real leaves under all $\mathrm{N}$ concentrations in the nutrient solution (Figure 3D).

Present results showed a maximum a consequence of the growing system. In the NFT system used by Darnell \& Stutte (2001) nutrients might diffuse from the rooting media into roots by mass flow, as reported by Gomez et al. (2003) in cucumber. In the soil or solid media roots have to grow for searching for water and nutrients. Concerning the $\mathrm{N}$ concentration in leaves, it might be affected by the growing season and leaf aging. At later summer, in perennial plants like strawberry growth and nutrient uptake decrease because physiological activity turns to senescence and dormancy.

Nitrate partitioning among organs was similar to that found by Haghighat et al. (2006), while in the Darnell \& Stutte (2001) publication, no effect of external $\mathrm{N}_{-} \mathrm{NO}_{3}{ }^{-}$concentrations higher than $3.75 \mathrm{mmol} \mathrm{L}^{-1}$ in the nutrient solution was observed on strawberry plant growth and fruit yield. They concluded that the enzyme nitrate reductase (NR) in roots and leaves of the strawberry plant saturates at that low external N concentration. Similar conclusion was reported by Cantliffe $e t$ al. (2007) on strawberry fruiting plants at the $\mathrm{N}^{-\mathrm{NO}_{3}}{ }_{3}$ concentration of $2.8 \mathrm{mmol}$ $\mathrm{L}^{-1}$ in the nutrient solution. However, present results suggest that during the propagation phase for runner tip production the saturation is reached at higher external concentrations, around $7.62 \mathrm{mmol} \mathrm{L}^{-1}$. The saturation of the $\mathrm{NR}$ at higher external $\mathrm{N}$ concentration than that used by Darnell \& Stutte (2001) and Cantliffe et al. (2007) may be ascribed to the $\mathrm{N}$ form in the nutrient solution. Although nitrate is the main form of $\mathrm{N}$ uptake by plants, it has been demonstrated in the literature that the addition of $\mathrm{N}_{-} \mathrm{NH}_{4}^{-}$modulates the relative uptake of anions and cations (Sonneveld, 2002) and consequently total $\mathrm{N}$ concentration in plant tissues (Tabatabaei et al., 2008). In the present

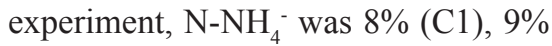
(C2), $23 \%(\mathrm{C} 3), 33 \%(\mathrm{C} 4)$ and $41 \%$ (C5), respectively. This was done to reach different $\mathrm{N}$ concentrations without changing the cation balance and the ionic equilibrium of the nutrient solution. In fact, reduced strawberry root and shoot growth has been reported in nutrient solutions using only one form 


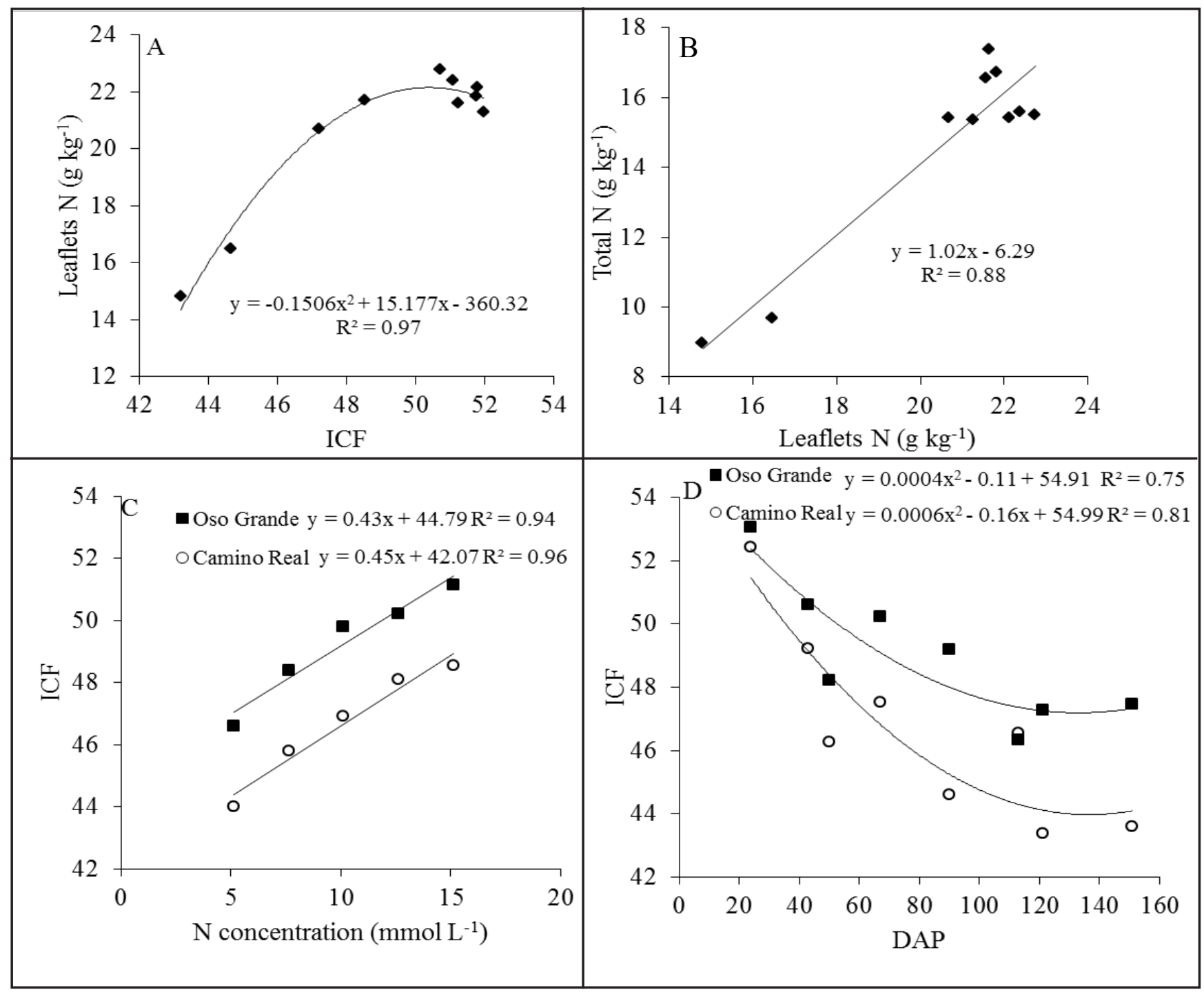

Figure 3. Relationship between the chlorophyll Index (ICF) and the nitrogen (N) concentration in leaflets of the whole plant (A), between $\mathrm{N}$ concentration in leaflets and total plant $\mathrm{N}$ concentration (B), values of the ICF of the last second full expanded leaf averaged over all the experimental period (C) and during the plant growing period, expressed by Days After Planting (DAP) (D) of Camino Real and Oso Grande strawberry stock plants grown under nitrogen $(\mathrm{N})$ concentrations from 5.12 to $15.12 \mathrm{mmol} \mathrm{L}^{-1}$ in the nutrient solution (relação entre o índice de clorofila (ICF) e a concentração de nitrogênio (N) nos folíolos da planta (A), entre a concentração de $\mathrm{N}$ nos folíolos da planta e a concentração de $\mathrm{N}$ total (B), valores médios do ICF da segunda folha expandida durante todo o período experimental (C) e no decorrer do período de crescimento, expresso em Dias Após o Plantio (DAP) em plantas matrizes de morangueiro (D) cultivadas em concentrações de nitrogênio entre 5,12 e 15,12 mmol L-1 na solução nutritiva). Santa Maria, UFSM, 2011.

of N (Sas et al., 2003; Tabatabaei et

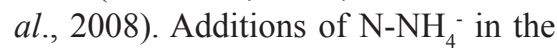
nutrient solution enhanced NR activity (Taghavi et al., 2004; Tabatabaei et al., 2008) and growth (Yoon et al., 2009). The nutrient solutions described in the literature for the strawberry crop contain from 3 to $20 \%$ of ammonium in its composition (Muckle, 1993; Sarooshi \& Cresswell, 1994). Present results confirm the benefits of using $\mathrm{N}_{-} \mathrm{NH}_{4}^{-}$in the nutrient solution for commercial production of strawberry runner tips.

While total $\mathrm{N}$ concentration did not increase above the external $\mathrm{N}$ concentration of $7.62 \mathrm{mmol} \mathrm{L}^{-1}$ in the nutrient solution, $\mathrm{NO}_{3}^{-}$concentration in plant tissues showed polynomial patterns (Figures 2A, B). This may be a consequence of disturbances in the plant water flux by salinity, because increasing the external $\mathrm{N}$ concentration increases also the EC of the nutrient solution. Physiological disturbances in strawberry plant growth like scorched leaves and tip burn symptoms at high nutrient solution concentrations have been reported in the literature (Guttridge et al., 1981;
Sonsteby et al., 2009) and were also observed mainly in $\mathrm{C} 4$ and $\mathrm{C} 5$ plants of the present experiment. In strawberry fruiting plants, reduction in vegetative growth and fruit yield at EC higher than $1.0-1.3 \mathrm{dS} \mathrm{m}^{-1}$ was recorded (Caruso et al., 2011). In the present experiment, the average $\mathrm{EC}$ in $\mathrm{C} 4$ and $\mathrm{C} 5$ were 1.76 and $2.0 \mathrm{dS} \mathrm{m}^{-1}$, respectively, and plant water flux and $\mathrm{NO}_{3}{ }^{-}$transport within the plant may have been reduced. However, $\mathrm{NO}_{3}{ }^{-}$accumulation represented only $13 \%$ of the total $\mathrm{N}$ in the plant, being $3.8 \%$ in leaflets, $27.8 \%$ in petioles, 
$16.5 \%$ in the crown and $11.5 \%$ in roots, on average of both cultivars. It can be concluded that $\mathrm{NO}_{3}{ }^{-}$accumulation in the strawberry plant is of minor importance. For commercial production of runner tips and strawberry plug plants, present results showed that total $\mathrm{N}$ concentration of the nutrient solution can be reduced to $5.12 \mathrm{mmol} \mathrm{L}^{-1}$, with $8 \%$ in the $\mathrm{NH}_{4}^{+}$ form.

At the end of the experiment, a polynomial relationship was adjusted between the chlorophyll index and the $\mathrm{N}$ concentration in leaflets in the range of external $\mathrm{N}$ concentrations in the nutrient solution between 5.12 and 15.12 mmol L ${ }^{-1}$ (Figure 3A). The maximum $\mathrm{N}$ concentration was $22.05 \mathrm{~g} \mathrm{~kg}^{-1}$ at an ICF of 50.5 (Figure 3A). When ICF readings during the experimental period were averaged, a linear relationship was fitted (Figure 3C). In strawberry fruiting plants, a linear relationship was also found by Güler et al. (2006). The polynomial pattern in the chlorophyll index (Figure 3D) might be ascribed to the developmental phase of the plant, because leaf growth in short day cultivars decreases and stops at later summer, starting the dormancy or semi dormancy period (Guttridge, 1985). A linear relationship was fitted between $\mathrm{N}$ in leaflets and in the whole plant (Figure 3B) and it can be concluded that the ICF can be used to estimate the $\mathrm{N}$ status of strawberry stock plants in the range between 43 and 50.5 ICF. Nevertheless, the fortnightly chlorophyll measurements made on the last second full expanded leaf of the main crown during the growing period (Figure 3D) showed a dilution pattern similar to that reported in the literature for several crops (Rattin et al., 2002; Skonieski et al., 2012). The crop nitrogen dilution curve has been explained as an allometric relationship between growth of plant metabolic compartments during its growth and development (Lemaire et al., 2008). During the vegetative growth phase, $\mathrm{N}$ is remobilized from shaded leaves at the bottom of the canopy to well illuminated ones at the top. In the reproductive phase, dry mass accumulation is shifted from leaves to storage and structural organs like stems, fruits, grains or tubers, having lower $\mathrm{N}$ concentration than leaves. In fruiting strawberry crops a reduction in $\mathrm{N}$ concentration in mature leaves has been previously reported (Cantliffe et al., 2007). At the propagative phase, such relationship has not yet been demonstrated. The present dilution curve represents the physiological ageing of the strawberry plant during its propagative phase. The ICF index was effective to show this process which has to be taken into account to estimate the plant $\mathrm{N}$ status during the growing period.

Present results indicate that the $\mathrm{N}$ concentration in the nutrient solution for growing strawberry stock plants can be modulated according to commercial purposes. When runner tips for plug transplants production is the main goal, it can be reduced to about 5 mmol L ${ }^{-1} \mathrm{~N}$. In the case vigorous plants are desired, as in clonal gardens for collecting meristematic tips for in vitro propagation, higher concentrations can be used. It can be concluded that leaflets and petioles are the organs of the strawberry stock plants with the highest $\mathrm{N}$ accumulation and that runner tips production is not affected by $\mathrm{N}$ concentrations of the nutrient solution in the range from 5.12 to $15.12 \mathrm{mmol} \mathrm{L}^{-1}$.

\section{ACKNOWLEDGEMENTS}

To Conselho Nacional de Desenvolvimento Científico e Tecnológico for financial support, grants 300998/2009-0 and 470255/2009-0 and fellowship. To Coordenação de Aperfeiçoamento de Pessoal de Nível Superior for a fellowship.

\section{REFERENCES}

ARCHBOLD DD; MACKOWN CT. 1997. Nitrogen availability and fruiting influence nitrogen cycling in strawberry. Journal of the American Society for Horticultural Science 122: 134-139.

BISH EB; CANTLIFFE DJ; CHANDLER CK. 2001. A system for producing large quantities of greenhouse grown strawberry plantlets for plug production. HortTechnology 11: 636-638.

CANTLIFFE DJ; CASTELLANOS JZ; PARANJAPE AV. 2007. Yield and quality of greenhouse-grown strawberries as affected by nitrogen level in coco coir and pine bark media. Florida State Horticultural Society 120: 157-161.

CARUSO G; VILLARI G; MELCHIONNA G; CONTI S. 2011. Effects of cultural cycles and nutrient solutions on plant growth, yield and fruit quality of alpine strawberry (Fragaria vesca) grown in hydroponics. Scientia Horticulturae 129: 479-485.

DARNELL R; STUTTE GW. 2001. Nitrate concentration effects on $\mathrm{NO}_{3}-\mathrm{N}$ uptake and reduction, growth, and fruit yield in strawberry. Journal of the American Society for Horticultural Science 5: 560-563.

GIANQUINTO G; FECONDINI M; MEZZETTI M; ORSINI F. 2010. Steering nitrogen fertilization by means of portable chlorophyll meter reduces nitrogen input and improves quality of fertigated cantaloupe (Cucumis melo var. cantalupensis). Journal of the Science of Food and Agriculture 90: 482-493.

GIMENEZ G; ANDRIOLO JL; GODOI R. 2008. Cultivo sem solo do morangueiro. Ciência Rural 38: 273-279.

GOMEZ MD; BAILLE A; GONZALEZ-REAL MM; MERCADER JM. 2003. Comparative analysis of water and nutrient uptake of glasshouse cucumber grown in NFT and perlite. Acta Horticulturae 614: 175-180.

GÜLER S; MACIT I; KOÇ A; IBRICKI H. 2006. Estimating leaf nitrogen status of strawberry by using chlorophyll meter reading. Journal of Biological Science 6: 1011-1016.

GUTTRIDGE CG. 1985. Fragaria $x$ ananassa. In: Haley AH. (eds) CRC Handbook of Flowering Vol. III. Florida: CRC Press Boca Ratón, p. 16-33.

GUTTRIDGE CG; BRADFIELD EG; HOLDER R. 1981. Dependence of calcium transport into strawberry leaves on positive pressure in the xylem. Annals of Botany 48: 473-480.

HAGHIGHAT AM; BABALAR M; KASHI A; EBADI A. 2006. The effect of $\mathrm{N}$ source on accumulation of nitrate in different organs of some strawberry cultivars. Iranian Journal of Agricultural Sciences 37: 821-830.

HENNION B; VESCHAMBRE D. 1997. Strawberry: control of production. Paris: CTIFL, 299p.

HISCOX JD; ISRAELSTAM GF. 1979. A method for the extraction of chlorophyll from leaf tissue without maceration. Canadian Journal of Botany 57: 1132-1334.

HOCHMUTH G; CANTLIFFE D; CHANDLER C; STANLEY C; BISH E; WALDO E; LEGARD D; DUVAL J. 2006. Containerized strawberry transplants reduce establishmentperiod water use and enhances early growth and flowering compared with bare root plants. HortTechnology 16: 46-54.

KARLIDAG H; YILDIRIM E; TURAN M. 2009. Salicylic acid ameliorates the adverse effect of salt stress on strawberry. Scientia Agricola 66: 180-187.

KIRSCHBAUMDS; LARSONKD; WEINBAUM SA; DEJONG TM. 2010. Late-season nitrogen applications in high-latitude strawberry nurseries improve transplant production pattern in warm regions. African Journal of Biotechnology 9: 1001-1007. 
LEMAIRE G; JEUFFROY MH; GASTAL FS. 2008. Diagnosis tool for plant and crop N status in vegetative stage: Theory and practices for crop N management. European Journal of Agronomy 28: 614-624.

MÉNDEZ EG; SIOVAS DG; ANDRADE MA; GONZÁLEZ B. 2009. Influence of nitrogen fertilization and digging date on strawberry plant maturity. Acta Horticulturae 842: 687-690.

MUCKLE ME. 1993. Hydroponic nutrients. 3ed. Princeton: Growers, 154p.

RATTIN JE; ANDRIOLO JL; WITTER M. 2002. Nitrogen concentration in dry matter of the fifth leaf during growth of greenhouse tomato plants. Horticultura Brasileira 20: 626-629.

SAROOSHI RA; CRESSWELL GC. 1994. Effects of hydroponic solution composition, electrical conductivity and plant spacing on yield and quality of strawberries. Australian Journal of Experimental Agriculture 34: 529-535.
SAS L; MARSCHNER H; RÖMHELD V; MERCIK S. 2003. Effect of nitrogen forms on growth and chemical changes in the rhizosphere of strawberry plants. Acta Physiologiae Plantarum 25: 241-247.

SKONIESKI FR; VIÉGAS J; CRUZ P; NORNBERG JL; BERMUDES FR; GABBI AM. 2012. Dynamics of nitrogen concentration on intercropped ryegrass. Acta Scientiarum 34: 1-6.

SONNEVELD C. 2002. Composition of nutrient solutions. In: Savvas D; Passam HC. (eds). Hydroponic production of vegetables and ornamentals. Athens: Embryo Publisher, p. 179-210.

SONSTEBY, A.; OPSTAD, N.; MYRHEIMA, U.; HEIDE, O.M. 2009. Interaction of short day and timing of nitrogen fertilization on growth and flowering of 'Korona' strawberry (Fragaria $x$ ananassa Duch.). Scientia Horticulturae 123: 204-209.

TABATABAEI SJ; YUSEFI M; HAJILOO J.
2008. Effects of shading and $\mathrm{NO}_{3}: \mathrm{NH}_{4}$ ratio on the yield, quality and $\mathrm{N}$ metabolism in strawberry. Scientia Horticulturae 116: 264-272.

TAGHAVI TS; BABALAR M; EBADI A; EBRAHIMZADEH H; ASGARI MA. 2004. Effects of nitrate to ammonium ratio on yield and nitrogen metabolism of strawberry Fragaria $\mathrm{x}$ ananassa cv. Selva). International Journal of Agriculture and Biology 6: 994-997.

TEDESCO MJ; GIANELLO C; BISSANI CA. 1995. Analysis of soil, plant and other materials. 2ed. Porto Alegre: UFRGS, 174p.

TWORKOSKI TJ; BENASSI TE; TAKEDAB F. 2001. The effect of nitrogen on stolon and ramet growth in four genotypes of Fragaria chiloensis. Scientia Horticulturae 88: 97-106.

YOON HS; HWANG YH; AN CG; SHIM JS; HWANG HJ; SHIN HY. 2009. Effect of $\mathrm{NH}_{4}^{+}$ to $\mathrm{NO}_{3}^{-}$ratio on growth, yield and albinism disorder of strawberry. Acta Horticulturae 842: 987-990. 